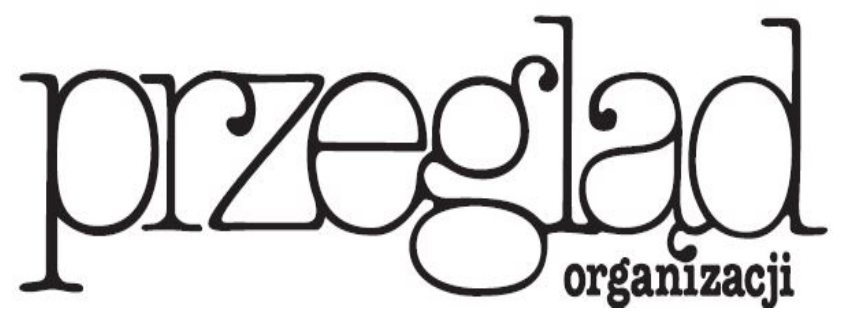

Miesięcznik TNOiK Założył Karol Adamiecki w 1926 r.

\title{
KOLEKTYWNA KLASTERYZACJA DANYCH MARKETINGOWYCH - SYSTEM REKOMENDACYJNY UPSAILY
}

https://doi.org/10.33141/po.2019.01.06

Jerzy Korczak, Maciej Pondel
Przegląd Organizacji, Nr 1 (948), 2019, ss. 42-52 www.przegladorganizacji.pl (cTowarzystwo Naukowe Organizacji i Kierownictwa (TNOiK)

\section{Wprowadzenie}

$\mathbf{P}$ ierwsze seminaria i konferencje lat 90. na temat systemów doradczych (Balabanovic, Shoham, 1997, s. 66; Goldberg i in., 1992, s. 61; Resnick, Varian 1997, s. 56) były znaczącym bodźcem gwałtownego zainteresowania nie tylko praktyki, ale i nauki metodami i technikami automatyzacji rekomendacji. W ostatnich latach pod wpływem rozwoju IT, sieci społecznościowych i metod sztucznej inteligencji pojęcie systemu rekomendacyjnego, jak też zakresu jego głównych funkcjonalności uległo znacznemu rozszerzeniu. Dzisiaj system rekomendacyjny to złożony interaktywny system pozwalający na wyznaczenie rangi produktu lub preferencji, jaką klient powinien przypisać danemu produktowi lub grupie produktów (Konstan, Adomavicius, 2013, s. 23). $\mathrm{W}$ literaturze system ten jest rozpatrywany $\mathrm{w}$ trzech głównych płaszczyznach. Z perspektywy menedżerskiej system rekomendacyjny to system wspomagania decyzji korzystający $\mathrm{z}$ dużych, heterogenicznych danych oraz mechanizmów generujących zalecenia związane ze strategią sprzedaży i promocją oferowanych produktów. $\mathrm{Z}$ perspektywy klienta to system ułatwiający dokonanie wyboru produktów zgodnie z jego zainteresowaniami, potrzebami i preferencjami. Z perspektywy informatycznej system rekomendacyjny to interaktywna platforma obliczeniowa zawierająca szereg modeli analizy i eksploracji danych, zintegrowana $z$ systemami transakcyjnymi i otoczeniem. Platforma ta musi zapewnić nie tylko dostęp do różnych zasobów informacyjnych, ale tė̇ skalowalność aplikacji operujących na bardzo licznych zbiorach informacji.

Konkretne korzyści ekonomiczne z personalizowanej rekomendacji osiągnięte przez potentatów e-commerce (Amazon, Alibaba, eBay, Booking, ...) przełożyły się na zwiększenie efektywności systemów rekomendacyjnych. Okazało się, że nie tylko wpłynęły na zwiększenie sprzedaży i na podniesienie skuteczności akcji marketingowych, ale też na znaczące ułatwienie analityczno-decyzyjne dla menedżerów marketingu. Współczesne 
systemy rekomendacyjne nie ograniczają się do podania zalecenia "kupiłeś ten produkt, ale inni co go kupili, kupili/oglądali jeszcze produkty X, Y, Z”. Wiele z nich opiera swoje rekomendacje również na podstawie cech produktu, profilu i analizy behawioralno-psychologicznej klienta.

Aktualnie w systemach wyróżnia się cztery kategorie mechanizmów doradczych: rekomendowanie przez zintegrowane filtrowanie informacji (collaborative filtering), rekomendowanie na podstawie cech kontekstowych produktów (content-based recommendation), rekomendowanie oparte na wiedzy (knowledge-based) i rekomendowanie hybrydowe (Beel, 2015; Jannach i in., 2012; s 76, Ricci i in., 2011, s. 1). Rekomendowanie poprzez zintegrowane filtrowanie informacji jest najbardziej rozpowszechnioną metodą polegającą na zaleceniu klientowi produktów wysoko ocenionych przez klientów o podobnym profilu i preferencjach (Acilar, Arslan, 2009, s. 8324; Cornuejols i in., 2017, s. 81; Kashef, Kamel, 2010, s. 2315). Kluczowymi problemami są tu: określenie miary podobieństwa pomiędzy klientami i wybór metody segmentacji klientów. Rekomendowanie na podstawie cech kontekstowych produktów opiera się na analizie i eksploracji dotychczas zakupionych przez klienta produktów (Balabanovic, Shoham, 1997, s. 66; Konstan, Riedl, 2012, s. 101). W odróżnieniu od poprzedniej metody, zasadniczą kwestią jest tu analiza historii zakupów danego klienta i określenie podobieństwa produktów. Trzecia grupa metod buduje zalecenia na podstawie analizy cech produktu pod kątem jego użyteczności dla klienta (Carmagnola i in., 2011, s. 285). W celu wykorzystania zalet i zredukowania wad wymienionych metod coraz częściej projektuje się hybrydowe systemy rekomendacyjne (Burke, 2002, s. 331).

Od kilku lat obserwuje się również w Polsce rosnące zainteresowanie systemami rekomendacyjnymi przez właścicieli i menedżerów sklepów internetowych. W roku 2010 co trzeci sklep internetowy korzystał z rekomendacji opartej na prostej analityce systemów CBR i Business Intelligence (Kobiela, 2011). W ostatnich latach w Polsce sztuczna inteligencja, personalizowana rekomendacja i cyfrowy marketing zdominowały orientację twórców systemów e-commerce, która do niedawna koncentrowała się na sprawności obsługi zakupów (https://www. gemius.pl/wszystkie-artykuly-aktualnosci/najnowsze-dane -o-polskim-e-commerce-juz-dostepne.html). Aktualnie większość dużych sklepów internetowych korzysta z systemów rekomendacyjnych. Jednakże systemy te w znacznej mierze są oparte na prostej analityce biznesowej, ograniczonej inteligencji obliczeniowej i możliwości dynamicznego profilowania klientów.

Celem artykułu jest przedstawienie metod analizy i profilowania klientów, dostępnych w systemie rekomendacyjnym Upsaily ${ }^{1}$ adresowanym do sklepów internetowych. Jest to system hybrydowy łączący techniki rekomendacji przez zintegrowane filtrowanie oraz poprzez analizę kontekstową. W opracowaniu zaleceń, oprócz danych transakcyjnych, system dodatkowo korzysta $z$ danych geolokalizacyjnych i społecznościowych. W syste- mie dane te są źródłem informacji dla wielu algorytmów analizy skupień, nazywanej w artykule klasteryzacją. Algorytmy te mogą pracować autonomicznie lub kolektywnie, współpracując ze sobą w celu osiągnięcia interesującej biznesowo i interpretowalnej semantycznie segmentacji. To drugie podejście jest przedmiotem artykułu. Mimo iż zbiór danych źródłowych jest taki sam, innowacyjność rozwiązania przejawia się $\mathrm{w}$ doborze algorytmów; każdy z nich został wybrany z innej klasy obliczeniowej i stosuje odmienne kryteria podobieństwa. Wśród algorytmów, oprócz powszechnie stosowanego algorytmu k-means korzystającego w grupowaniu z miary dystansu euklidesowskiego, został wybrany do eksperymentu Gaussowki Model Mieszany oparty na rozkładach prawdopodobieństwa obserwacji, algorytm DBSCAN, biorący pod uwagę kryterium gęstości obserwacji oraz algorytm klasteryzacji $\mathrm{z}$ podpowiedzią analityka wspomaganego metodą RMF. Unifikacja rezultatów klasteringu w aplikacji Upsaily nie dotyczy wszystkich klastrów, lecz jednego czy kilku oraz jest specyficzna dla aplikacji e-commerce. Kryteria wyboru obejmują zarówno kryteria statystyczne, jak i kryteria zewnętrzne, głównie ekonomiczne.

Struktura artykułu jest następująca. W kolejnym rozdziale opisano główne funkcjonalności systemu rekomendacyjnego Upsaily i naszkicowano jego architekturę funkcjonalną. Następnie zdefiniowano problem klasteryzacji kolektywnej wraz z podaniem specyfikacji użytych algorytmów. Uszczegółowiono też pojęcia miar podobieństwa i kryteriów unifikacji rezultatów klasteryzacji. Ostatnia część artykułu jest rozdziałem eksperymentalnym, w którym pokazano na rzeczywistych danych walory klasteryzacji kolektywnej.

\section{Architektura funkcjonalna i funkcjonalności systemu Upsaily}

$\mathrm{S}$ ystem Upsaily, oparty na modelu e-commerce, zorientowany jest na obecnych klientów sklepu internetowego. W bazie danych systemu zapamiętane są nie tylko wszystkie transakcje klientów, ale również podstawowe dane o ich profilu behawioralnym i demograficznym. System jest w stanie rejestrować reakcje klienta na oferty, które są do niego adresowane poprzez różne kanały kontaktu. Funkcjonalnie system można sklasyfikować jako rozwiązanie Customer Intelligence, czyli takie, którego podstawowym obiektem zainteresowań są obecni klienci, a celem zwiększenie satysfakcji klienta wyrażonej w zwiększeniu obrotów poprzez dokonywanie przez niego kolejnych zakupów, zwiększanie wartości poszczególnych zamówień poprzez dokupowanie produktów powiązanych (cross-selling) bądź produktów bardziej wartościowych (up-selling). Należy zaznaczyć, że bezpośrednim celem systemu nie jest wspomaganie w pozyskiwaniu nowych klientów. Podejście Customer Intelligence związane jest $\mathrm{z}$ prowadzeniem działań analitycznych zmierzających do stworzenia jasnego obrazu klienta po to, aby można było wyszukiwać najbardziej wartościowych klientów oraz kierować do nich spersonalizowany do ich potrzeb przekaz marketingowy (Nazemoff, 2014). 
Powodem takiej orientacji systemu były wyniki badań przeprowadzonych w ramach projektu RTOM na polskich sklepach internetowych działających w różnych branżach. Pokazały one, że w każdym z nich przeszło 75\% wszystkich klientów to klienci jednorazowi - czyli tacy, którzy po dokonaniu zakupu nigdy więcej nie powrócili do sklepu. Analiza średniej wartości zamówienia dla klienta jednorazowego pokazała, że była ona niższa niż w przypadku klientów, którzy dokonali kolejnych zakupów. Co ciekawe, można zauważyć generalny trend wzrostu średniej wartości zamówienia wraz ze wzrostem lojalności klienta wyrażonej w liczbie dokonanych przez niego zakupów. Z obserwacji tej wyciągnięto wniosek, że warto poświęcić energię sklepu internetowego na budowanie lojalności klientów, gdyż lojalny klient jest w ostatecznym rozrachunku bardziej wartościowy niż klient jednorazowy.

Należy również pamiętać, że pozyskanie nowego klienta jest zawsze związane $\mathrm{z}$ konkretnym kosztem, jaki trzeba ponieść, aby dotrzeć do klienta $\mathrm{z}$ przekazem marketingowym w wybranym kanale marketingowym. W praktyce zazwyczaj pozyskuje się klienta, kierując do niego przekaz ogólny. Jednakże nie znając poprzednich transakcji klienta, niemożliwe jest zaproponowanie efektywnej, dedykowanej do potrzeb klienta oferty. W związku z tym w większości przypadków prezentacja komunikatu marketingowego nie spotyka się z oczekiwaną reakcją klientów. $\mathrm{W}$ przypadku komunikacji $\mathrm{z}$ obecnymi klientami, których danymi kontaktowymi firma handlowa dysponuje oraz w przypadku których ma wszystkie niezbędne zgody marketingowe - przynajmniej na poziomie założeń, można określić, że dotarcie do klienta powinno kosztować zdecydowanie mniej, a skuteczność komunikatów powinna być zdecydowanie wyższa.

Bazując na badaniach literaturowych (Chorianopoulos, 2016; Gordon i in., 2011; Jordan, Mitchell, 2015, s. 255) oraz formułując wnioski z badań prowadzonych w ramach projektu RTOM, zaproponowano w artykule schemat prowadzenia zaawansowanych analiz danych w marketingu pokazany na rysunku 1 .

Schemat jest pomocny w organizacji działań marketingowych. W zależności od określonego celu wyznacza się grupę klientów, którzy powinni zostać objęci kampanią. Na ogół, dla zdefiniowanych klientów wybiera się przedmiot kampanii, np. grupy produktów, którymi będą oni potencjalnie zainteresowani. Ostatnim etapem jest określenie warunków, na jakich zaproponuje się klientom udział w kampanii. Jak pokazuje zaprezentowany schemat, algorytmy klasteringu mają $\mathrm{w}$ tym podejściu fundamentalne znaczenie.

Architektura logiczna systemu została zaprezentowana na rysunku 2. System Upsaily korzysta z wielu źródeł informacyjnych, jednak podstawą jego analiz są dane transakcyjne. Dane z innych źródeł, takich jak: systemy marketing automation, media społecznościowe, systemy analizujące aktywność na stronie sklepu, wzbogacają profil klienta i przyczyniają się do opracowania pełniejszych analiz oraz lepszych modeli predykcyjnych.

W architekturze systemu znaczące miejsce zajmuje platforma badawcza, na której przeprowadzane są eksperymenty. Rezultaty eksperymentów są oceniane pod kątem przydatności biznesowej, a w momencie gdy ich efekty są pozytywne, wówczas zamieniane są w regularne moduły działające w sposób produkcyjny.

Jak pokazano na rysunku 2, wyjścia informacyjne systemu są zintegrowane $\mathrm{z}$ :

- panelem marketingowym prezentującym wyniki prowadzonych analiz, który wizualizuje zidentyfikowane trendy, odnalezione wzorce oraz efekty segmentacji. Odbiorcami są przede wszystkim menedżerowie oraz analitycy marketingu, którzy z jego pomocą poszerzają własną wiedzę o klientach i ich zachowaniach,

- rekomendatorem działającym w czasie rzeczywistym, który proponuje klientowi odwiedzającemu sklep internetowy ofertę, możliwie najbardziej dopasowaną do jego potrzeb,

- modułem „kampanie na dziś”, który na podstawie odnalezionych trendów oraz wzorców zachowań klientów jest $\mathrm{w}$ stanie $\mathrm{w}$ momencie uruchomienia automatycznie wskazać grupy klientów oraz produkt, którym mogą być zainteresowani w danej chwili.

Przykładowe wyniki pracy systemu Upsaily zostaną przedstawione w następnych rozdziałach artykułu.

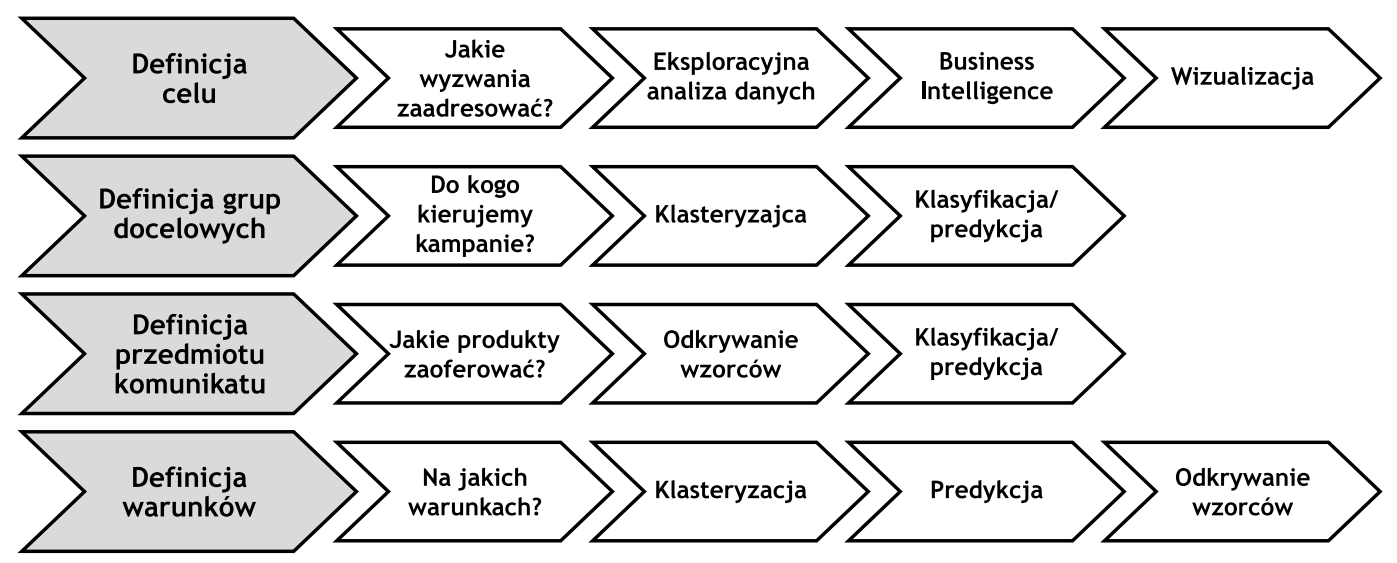

Rys. 1. Etapy budowania komunikatu marketingowego wraz z propozycją wykorzystania metod oraz narzędzi analizy danych

Źródło: opracowanie wtasne 


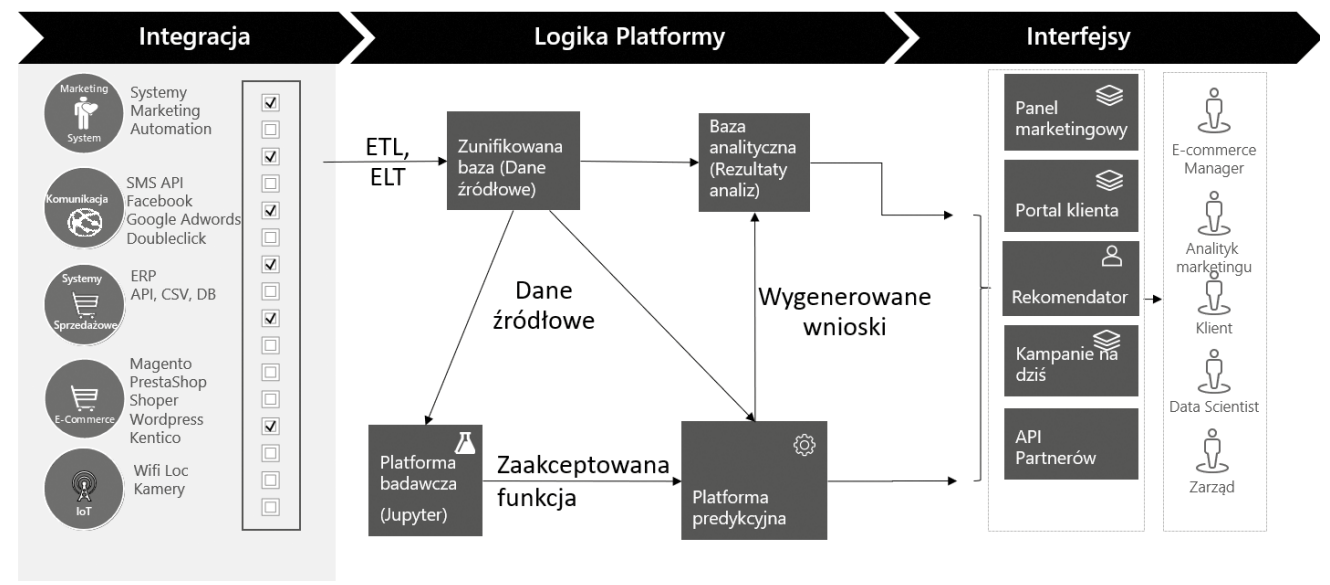

Rys. 2. Architektura logiczna systemu Upsaily Źródło: opracowanie własne

\section{Metody oceny kolektywnej klasteryzacji}

stnieje wiele metod klasteryzacji (Aggarwal, Reddy, 2013; Gordon, 2011). Zaproponowana w artykule metoda kolektywnej klasteryzacji ma charakter uniwersalny i nie jest zależna od kategorii i liczby użytych algorytmów. W celu ilustracji przyjętego podejścia $\mathrm{w}$ przedstawionych badaniach wykorzystano następujące algorytmy:

- k-means bazujący na euklidesowej odległości pomiędzy obserwacjami,

- bisecting k-means działający na podobnej zasadzie co k-means, jednak zaczynający od wszystkich obserwacji znajdujących się w jednym klastrze, a następnie dzielący klaster na 2 podklastry, używając algorytmu $\mathrm{k}$-means,

- Gaussowki Model Mieszany (ang. Gaussian Mixture Model, GMM), który jest modelem probabilistycznym bazującym na założeniu, że poszczególna cecha ma skończoną liczbę rozkładów normalnych,

- DBSCAN identyfikujący klastry poprzez pomiar gęstości obserwacji w wyznaczonym obszarze.

$\mathrm{Z}$ reguły wyniki algorytmów klasteryzacji ocenia się według kryteriów wewnętrznych i zewnętrznych. Kryteria wewnętrzne dotyczą hierarchii klastrów, biorąc pod uwagę podobieństwo obserwacji wewnątrz klastrów i podobieństwo pomiędzy klastrami. Wśród miar oceny stosowane są zazwyczaj wskaźniki Daviesa-Boudina ${ }^{1}$ i Dunna ${ }^{3}$. Oprócz wymienonych wskaźników stosowane są inne miary oceny, takie jak wskaźnik silhouette, miary spójności klastrów, miary separacji klastrów, macierz rozrzutu wewnątrzklasowego (Aggarval, 2013; Gan, 2007).

Według kryteriów zewnętrznych, wyniki klasteryzacji oceniane są przy wykorzystaniu danych zewnętrznych, niebranych pod uwagę $\mathrm{w}$ procesie klasteryzacji. Takimi danymi są obserwacje, których przynależność do klastra jest oznaczona wcześniej przez ekspertów. Wówczas ocena klasteryzacji wynika $\mathrm{z}$ porównania zawartości klastrów oznaczonych przez ekspertów z klastrami utworzonymi przez algorytm. Wśród stosowanych miar należy wymienić wskaźnik jednorodności klastrów ${ }^{4}$, wskaźnik Jaccarda ${ }^{5}$, wskaźnik Randa ${ }^{6}$. Oprócz podanych miar, w ocenie klasteryzacji stosuje się też inne wskaźniki, takie jak Kappa, F-score, wskaźnik Fowkesa-Mallowsa, ... (Aggarval, 2013; Gan, 2007).

W przypadku użycia wielu algorytmów klastrujących otrzymane wyniki na ogół różnią się od siebie nie tylko liczbą i hierarchią klastrów, ale też przyporządkowaniem obserwacji do klastrów. W artykule autorzy traktują zbiór algorytmów jako kolektyw ekspertów, którego zadaniem jest dokonanie możliwie najlepszego z punktu widzenia biznesu podziału zbioru obserwacji. Rozbieżności w grupowaniu przejawiajace się $\mathrm{w}$ wynikach zastosowanych algorytmów powinny być zminimalizowane. Rozwiazanie tego problemu określa opisany dalej proces unifikacji.

Interpretacja wyników klasteryzacji polega na przypisaniu klasy i podaniu reguł klasyfikacyjnych zgrupowanym obserwacjom. W przypadku bardzo licznych zbiorów nie jest możliwe oznaczenie wszystkich obserwacji przez ekspertów. Dlatego w systemie postanowiono umożliwić oznaczanie obserwacji w klastrach poprzez reguły decyzyjne interpretujące wybrane przez eksperta klastry, o postaci:

$$
X_{i} \in C_{j} \mid j e s ́ l i\left[( w _ { 1 1 } \cap w _ { 1 2 } \cap \ldots \cap w _ { 1 k } ) \cup \left(w_{21} \cap w_{22} \cap \ldots\right.\right.
$$

gdzie $X_{i}$ oznacza daną obserwację, $C_{j}$ klaster, $w_{l}$ wyrażenie warunkowe. Atrybuty użyte w wyrażeniach warunkowych wskazują na ich rangę i użyteczność w charakterystyce klastrów.

W systemie Upasily reguły decyzyjne są wyznaczane przez algorytm drzew indukcyjnych C4.5 (Quinlan, 1996, s. 77). Reguły te pozwalają z jednej strony zinterpretować otrzymane klastry, a z drugiej wyznaczyć obserwacje należace do poszczególnych klastrów. To umożliwi w przypadku użycia wielu algorytmów grupujących łatwe odszukanie podobnych semantycznie klastrów. Interpretacja symboliczna klastrów uzupełniona jest graficznie, co pozwala na szybką identyfikację podobnych klastrów. Zaznaczyć należy, że prace te wymagają znacznego zaangażowania analityków marketingu. 
Na ogól, w systemach rekomendacyjnych interesujące jest jedynie kilka klastrów opisujacych podobnych klientów, podobne produkty lub podobne transakcje. Stąd pierwszym zadaniem analityka jest określenie klastrów będących dalej przedmiotem unifikacji. Wprawdzie zadanie to można wykonać algorytmicznie, ale doświadczenia autorów pokazały, że znacznie lepsze wyniki uzyskuje się poprzez preselekcję klastrów przez analityka. Jeśli selekcja wizualna jest trudna, to w znalezieniu dla danego klastra $C_{i}$ odpowiednika wśród klastrów $C_{j} \in C_{k}$ otrzymanych $\mathrm{z}$ innego algorytmu można posłużyć się formułą podobieństwa między klastrami $S\left(C_{i}, C_{j}\right)$ według wzoru:

$$
S\left(C_{i}, C_{j}\right)=\max \left(\left|C_{i} \cap C_{j}\right| /\left|C_{i}\right|\right)
$$

W przypadkach kiedy obserwacje klastra $C_{i}$ rozkładają się na kilka klastrów z $C_{k}$, należy wziąć pod uwagę przy obliczeniach rozkład wartości $S$ i odpowiednio zważyć wartości podobieństwa klastra.

Po wyborze klastrów otrzymanych $\mathrm{z}$ różnych algorytmów można przystąpić do unifikacji wyników.

Istnieje wiele metod unifikacji. Do najczęściej stosowanych zalicza się:

- metody consensusu (Strehl, Ghosh, 2002, s. 583; Ayad, Kamel, 2008, s. 160; Nguyen, Caruana, 2007, s. 607; Pedrycz, 2007, s. 1), które używane są bardziej w pierwszej fazie unifikacji do utworzenia początkowej klasteryzacji aniżeli do unifikacji rezultatów,

- metody grupowania wielokryterialnego (Law i in., 2004, s. 424) stosowane są głównie w celu ujednolicenia kryteriów różnych algorytmów,

- metody klasteringu wsparte wiedzą dziedzinową (Wagstaff i in., 2001, s. 557).

W systemie Upsaily wykorzystano ostatnią grupę metod unifikacji. Wiedza dziedzinowa marketingu posłużyła do ukierunkowania procesu ujednolicenia wybranych klastrów. Skorzystano tu z utworzonych wcześniej reguł decyzyjnych, których wyrażenia warunkowe potraktowano jako ograniczenia grupowania obserwacji. Idea zaproponowanej metody polega na wyznaczeniu semantycznych relacji - ograniczeń wskazujacych na obserwacje, które muszą być włączone do klastra (must-link), a które nie powinny być $\mathrm{w}$ nim zawarte (cannot-link). W celu podniesienia jakości klastrów w niektórych pracach stosowana jest logika rozmyta (Grira i in., 2008, s. 1851) lub charakterystyki klastrów, takie jak wartości dystansu, gęstości.

Celem procesu unifikacji jest osiągnięcie consensusu odnośnie do zawartości finalnego klastra, bez znacznej straty jakości podziału. Załóżmy, że zostały wstępnie wyznaczone jako podobne dwa klastry $C_{j}$ i $C_{l}$, każdy $\mathrm{z}$ innego algorytmu. Interpretacja każdego $\mathrm{z}$ klastrów może być podana w postaci reguł decyzyjnych, mianowicie:

$$
\begin{gathered}
C_{j} \mid \text { jeśli }\left[( w _ { 1 1 } ^ { \prime } \cap w _ { 1 2 } ^ { \prime } \cap \ldots \cap w _ { 1 k } ^ { \prime } ) \cup \left(w_{21}^{\prime} \cap w_{22}^{\prime} \cap \ldots\right.\right. \\
\left.\left.\cap w_{2 m}^{\prime}\right) \ldots\right] \\
C_{l} \mid \text { jeśli }\left[( w ^ { \prime \prime } { } _ { 1 1 } \cap w ^ { \prime \prime } \cap \ldots \cap w _ { 1 2 } ^ { \prime \prime } ) \cup \left(w^{\prime \prime}{ }_{21} \cap w^{\prime \prime}{ }_{22} \cap \ldots\right.\right. \\
\left.\left.\cap w^{\prime \prime}{ }_{2 m}\right) \ldots\right]
\end{gathered}
$$

Finalny klaster może powstać poprzez scalenie warunków zawierajacych zmienne (atrybuty) wskazane przez analityka na podstawie wiedzy dziedzinowej. Operację tę można nazwać subsumcją, według której warunek bardziej szczegółowy zostanie pokryty mniej szczególowym. Jednakże, jak pokazono na rysunku 3, powstały klaster może zawierać zbyt dużo obserwacji zbyt odległych od poszukiwanej klasy. W zawężeniu przestrzeni klastra mogą pomóc podane wcześniej przez eksperta obserwacje, określone jako must-link lub cannot-link, oznaczone na rysunku odpowiednio kółkiem oraz trójkątem.

Granica finalnego klastra (linia przerywana) jest wyznaczona pomiędzy sumą obserwacji należących do dwóch klastrów pomniejszoną o otoczenie $\varepsilon$ obserwacji należących do relacji cannot-link $a$ intersekcją obserwacji powiększonej o otoczenie $\varepsilon$ obserwacji należących do relacji must-link. Można zatem zapisać, że do zunifikowanego klastra należą obserwacje leżące w przestrzeni pomiędzy $\left|C_{i} \cup C_{j}\right|-\varepsilon X_{i}$ /cannot-link a $\left|C_{i} \cap C_{j}\right|+\varepsilon X_{i} /$ must-link. Promień otoczenia $\varepsilon$ może być wyznaczony na podstawie $1 / 2$ dystansu pomiędzy najbliższymi obserwacjami należącymi do relacji cannot-link i must-link.

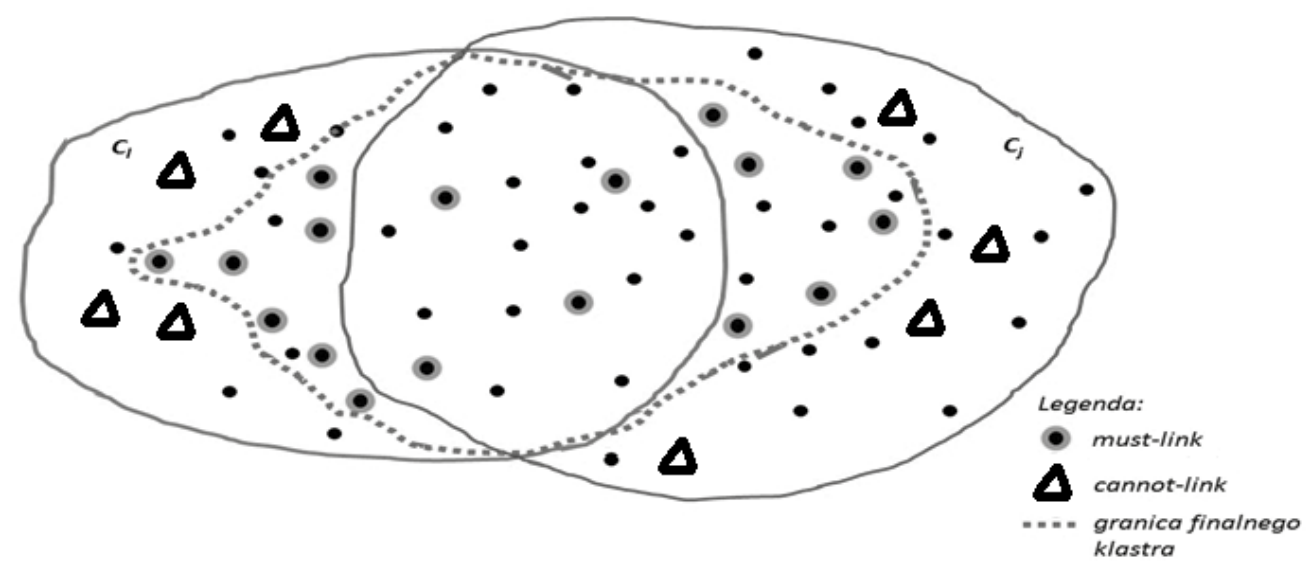

Rys. 3. Przestrzeń unifikacji klastrów Źródto: opracowanie wtasne 
Po przeprowadzeniu pierwszej unifikacji klastrów proces należy powtórzyć dla wszystkich podobnych klastrów otrzymanych, ze wszystkich zastosowanych algorytmów. Należy zaznaczyć, że kolejność doboru par klastrów ma znaczenie dla czasu obliczeń. Sugerujemy tu wybór w pierwszej kolejności najliczniejszych klastrów będących przedmiotem zainteresowań analityka. W następnym rozdziale zostaną pokazane przykłady unifikacji rezultatów kolektywnej klasteryzacji.

$\mathrm{Z}$ uwagi na ograniczone ramy artykułu w następnym rozdziale autorzy skoncentrują się tylko na ocenie biznesowej rezultatów klasteringu (wiedzy dziedzinowej). Wykorzystano tutaj analizę RFM, która jest tradycyjnym podejściem do analizowania zachowań klientów w branży detalicznej. W tym typie analizy dzieli się klientów na grupy według tego, jak dawno dokonali zakupów, jak często dokonują zakupów i jaką kwotę na nie wydali (Linoff, 2015).

Analiza RFM jest interesująca dla analityków danych marketingowych $\mathrm{z}$ uwagi na fakt, że pozwala na zbadanie użytecznych biznesowo hipotez czy:

- klienci, którzy dokonali ostatnio zakupów, będą skłonni dokonać wkrótce następnego zakupu,

- klienci, którzy często dokonują zakupu, będą skłonni do zrobienia więcej zakupów,

- klienci, którzy wydają dużo pieniędzy, będą bardziej skłonni wydać więcej następnym razem.

Zauważyć należy, że każda $\mathrm{z}$ tych hipotez wiąże się z jednym $z$ wymiarów RFM.

\section{Wyniki badań eksperymentalnych}

W celu pokazania użyteczności metody kolektywnej klasteryzacji w konkretnych warunkach biznesowych w tym rozdziale przedstawiono eksperyment, którego celem jest znalezienie segmentów klientów o podobnym zachowaniu się na rynku. Z założenia metoda klasteryzacji powinna pomóc $\mathrm{w}$ przypisaniu klientów do poszczególnych profili, ocenie poszczególnych segmentów oraz interpretacji cech charakterystycznych tych segmentów. W opisie segmentów rynku wykrzystano w systemie metodę RFM. Klient jest opisany poprzez częstotliwość dokonywania przez niego zakupów (wymiar frequency na podanych dalej wizualizacjach widoczny jako frequency), datę, jaka upłynęła od ostatniego zamówienia (wymiar recency na wizaulizacjach widoczny jako recency) i średnią wartość zamówienia (wymiar monetry value na wizualizacjach widoczny jako average order value). Dodatkowo do opisu klienta dodano informację o liczbie zamówień, która jest podstawą określenia lojalności klienta (na wizualizacjach number of orders). Klientów podzielono na sześć segmentów i dla każdego obliczono wartość wszystkich zamówień klientów. Liczbę segmentów wybrano arbitralnie z uwagi na możliwość przygotowania sześciu różnych polityk komunikacji marketingowej kierowanej do poszczególnych klientów. Zaznaczmy, że przy większej liczbie segmentów byłoby bardzo trudno dokonać ich interpretacji przez analityka marketingu celem opracowania dla wybranych klientów dedykowanej polityki komunikacyjnej. Większa liczba segmentów może mieć uzasadnienie tylko w przypadku, gdy z segmentacji będzie korzystał automatyczny mechanizm rekomendujący.

Eksperyment został przeprowadzony z wykorzystaniem trzech algorytmów klastrujących: bisecting k-means, Gaussowki Model Mieszany oraz DBSCAN7. Wyniki każdego z algorytmów zostały ocenione przez eksperta. Analizie zostało poddanych 56237 klientów, którzy dokonali w sklepie internetowym co najmniej 2 zakupów.

Przy ocenie segmentacji przydatna była wizualizacja danych, która została przeprowadzona za pomocą dwóch metod służących do rzutowania przestrzeni wielowymiarowej na mniejszą liczbę wymiarów, mianowicie Principal Component Analysis ${ }^{8}$ (PCA) (Ghodsi, 2006, s. 38) i Uniform Manifold Approximation and Projection (UMAP) (McInnes, Healy, 2018). W prezentacji wyników z uwagi na czytelność wizualizacji w eksperymencie zmniejszono cztery wspomniane wymiary do dwóch (X oraz Y), natomiast kolorem szarości wskazano numer segmentu, do którego trafił dany klient.

Przykład segmentacji RFM dokonanej przy użyciu algorytmu k-means oraz wizualizacji przy użyciu metody PCA został zaprezentowany na rysunku 4 . Na wizualizacji jedna kropka oznacza jednego klienta. W systemie po najechaniu kursorem na wybraną kropkę można prześledzić wartości opisujące wybranego klienta. Takie rozwiązanie pomaga $\mathrm{w}$ zrozumieniu otrzymanych segmentów.

W prawej części rysunków na wykresach lejkowych (funnel chart) pokazano dla każdego analizowanego wymiaru średnią wartość atrybutu w poszczególnych segmentach; przykładowo, że klienci $\mathrm{z}$ segmentu nr 1 mają średnią częstotliwość zakupów 14,22 dnia.

Wykres kolumnowy zlokalizowany w prawym dolnym rogu rysunku prezentuje sumę wartości zamówień klientów w poszczególnych segmentach. Można zatem zauważyć, że największy przychód został wygenerowany przez klientów z segmentu $\mathrm{nr} 6$, natomiast najmniejszy w segmencie nr 5.

Drugą metodą zastosowaną w systemie do redukcji wymiarów była metoda Uniform Manifold Approximation and Projection (UMAP). Jest to nowa metoda będąca konkurencyjną $\mathrm{w}$ stosunku do metody t-SNE, która jest obecnie uznawana za standard wśród nowoczesnych metod redukcji wymiarów. Jest ona oparta na geometrii nieeuklidesowskiej Riemanna i bazuje na aproksymacji lokalnej rozmaitości (local manifold approximations) oraz rozmytych zbiorach symplicjalnych. W odróżnieniu od metody prostej, takiej jak PCA, gdzie rzutowanie oparte jest w głównej mierze na dwóch wymiarach, metoda UMAP bierze pod uwagę wszystkie wymiary $\mathrm{w}$ równym stopniu. Przykład wizualizacji wykonanej za pomocą metody UMAP został zaprezentowany na rysunku 5.

Wizualizacja za pomocą dwóch metod, a także prezentacja wartości poszczególnych wymiarów w klastrach 


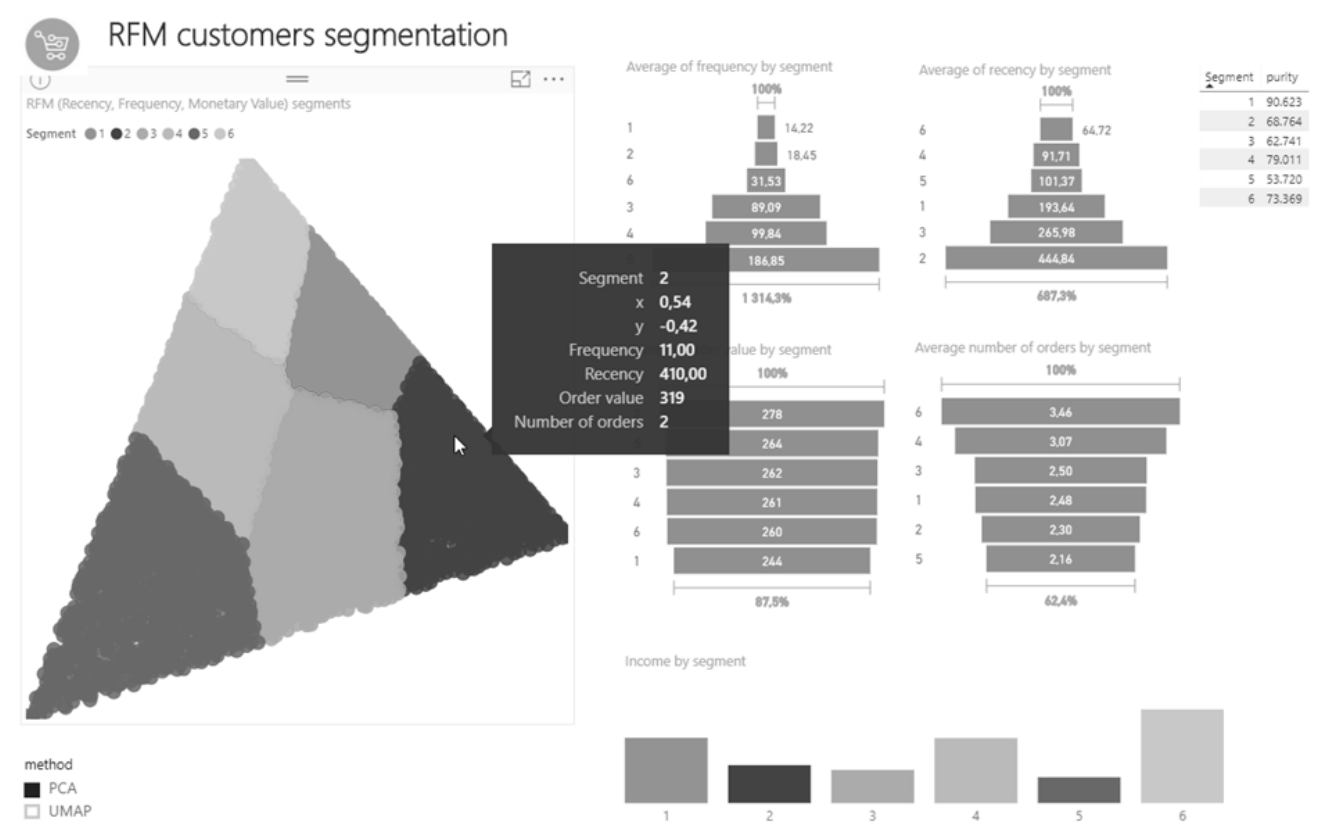

Rys. 4. Segmentacja przy użyciu algorytmu k-means oraz wizualizacja metodą PCA Źródło. opracowanie wtasne w platformie Upsaily

pozwalają analitykowi lepiej zinterpretować poszczególne segmenty klientów oraz dokonać oceny klasteryzacji.

Klasteryzacja przy użyciu algorytmu k-means bazującego na euklidesowej odległości pomiędzy obserwacjami ma niestety sporo wad. Można do nich zaliczyć fakt, że przy przydzielaniu klientów do segmentów największy wpływ mają najbardziej zróżnicowane wartości wymiarów (w naszym przypadku recency oraz frequency). Pozostałe wymiary mają mniejszy wpływ, co widać też $\mathrm{w}$ niskim zróżnicowaniu wymiarów wartości zamówień oraz liczby zamówień. Do zalet tego algorytmu można zaliczyć stosunkowo duże zrównoważenie poszczególnych segmentów (ich liczność jest relatywnie zbliżona). Zauważyć należy jednakże, że granice pomiędzy poszczególnymi segmentami nie są ostre. Dla przykładu do segmentu nr 6, mającego najniższą średnią wartość wymiaru recency, wpadli zarówno klienci $\mathrm{z}$ wartością 0 , jak i klienci $\mathrm{z}$ wartością 147, czyli z perspektywy metody RFM tacy, którzy zakupu dokonali stosunkowo dawno.

Kolejnym algorytmem klasteryzacji użytym w eksperymencie był algorytm bisecting k-means. $\mathrm{W}$ przypadku tego algorytmu zaobserwowano większą różnorodność na poszczególnych wymiarach niż $\mathrm{w}$ przypadku algorytmu k-means. Klastry były ponownie stosunkowo zrównoważone, niemniej jednak pozostał problem niewielkiego zróżnicowania jednego wymiaru, a w niektórych segmentach znaleźli się klienci bardzo oddaleni od średniej wartości na danym wymiarze.

Kolejne grupowanie zostało wykonane przy użyciu algorytmu Gaussowki Model Mieszany (GMM). W rezultatach grupowania można zaobserwować znaczne zróżnicowanie wartości poszczególnych wymiarów, dzięki któremu możemy zwrócić uwagę na interesujące przypadki wartości odstających (np. segment $\mathrm{nr}$
1 klientów o bardzo dużej liczbie zamówień i bardzo dużej wartości zamówień). Niestety, liczność takich segmentów jest stosunkowo mała (w tym przypadku 34 osoby), co stawia pod znakiem zapytania zasadność budowania specjalnej polityki komunikacyjnej skierowanej do klientów z takiego segmentu.

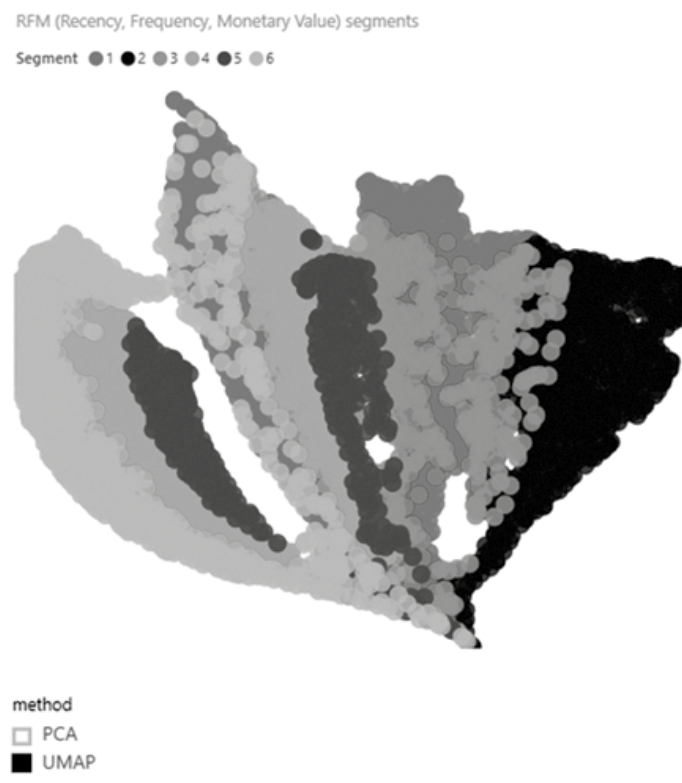

Rys. 5. Wizualizacja segmentacji przy użyciu metody UMAP Źródto: opracowanie wtasne w platformie Upsaily

Ten sam eksperyment powtórzono dla algorytmu DBSCAN. W przypadku tego algorytmu nie zadano liczby klastrów, a jedynie ustalono minimalną wielkość klastra. Pozytywnym efektem klasteryzacji było większe zróżnicowanie wartości średnich wymiarów 
we wskazanych segmentach. Wadą natomiast był brak przyporządkowania do klastrów sporej części obserwacji, a także to, że większość klastrów była bardzo mało liczna. $\mathrm{Z}$ tych względów wykorzystanie tego algorytmu do budowania polityk komunikacyjnych było dyskusyjne.

Generalnie aby analityk marketingu mógł wykorzystać klasteryzację za pomocą wszystkich wskazanych algorytmów, powinien najpierw zaobserwować zidentyfikowane na poszczególnych wymiarach granice, a następnie użyć ich do zbudowania własnych klastrów. Przykładowe interpretacje ilustrują poniższe przykłady: jeśli average order value $>1000$ zł oraz number of orders $>10$ oraz recency $<300$ oraz frequency $<60$ to segment $=$ „aktywny, wartościowy i często kupujacy ”

jeśli average order value $<200 \mathrm{z}$ oraz number of orders $>10$ oraz recency $>250$ oraz frequency $>200$ to segment = "Okazjonalni, mało aktywni, kupujacy tanio"

W platformie Upsaily możliwe jest „ręczne” filtrowanie klientów celem przypisania do klastrów przy użyciu dostarczonych „suwaków” zaprezentowanych w prawym górnym rogu na rysunku 6.

W ostatniej fazie eksperymentu zaproponowano segmentację kolektywną biorącą pod uwagę pozytywne
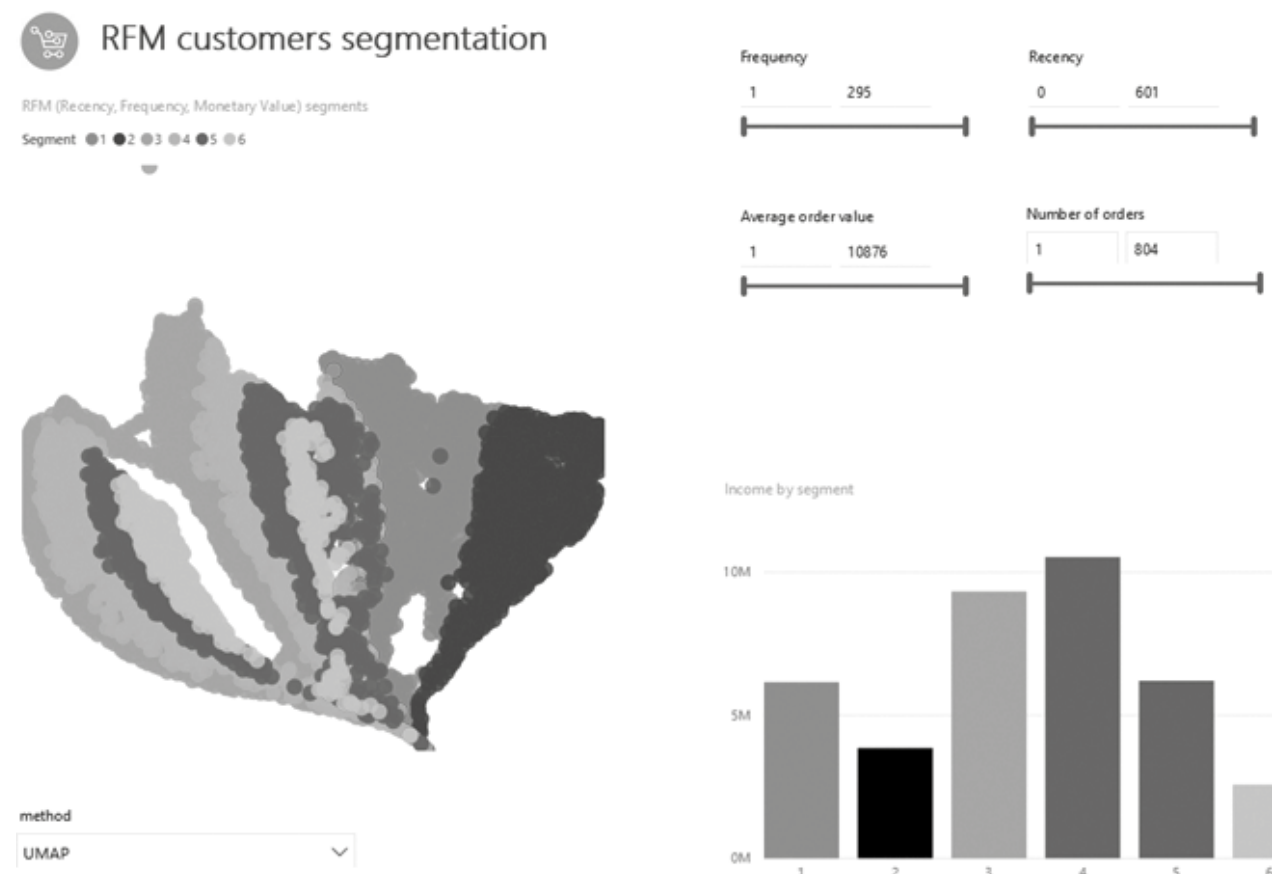

Rys. 6. Segmentacja „ręczna” w platformie Upsaily Źródło: opracowanie wtasne w platformie Upsaily
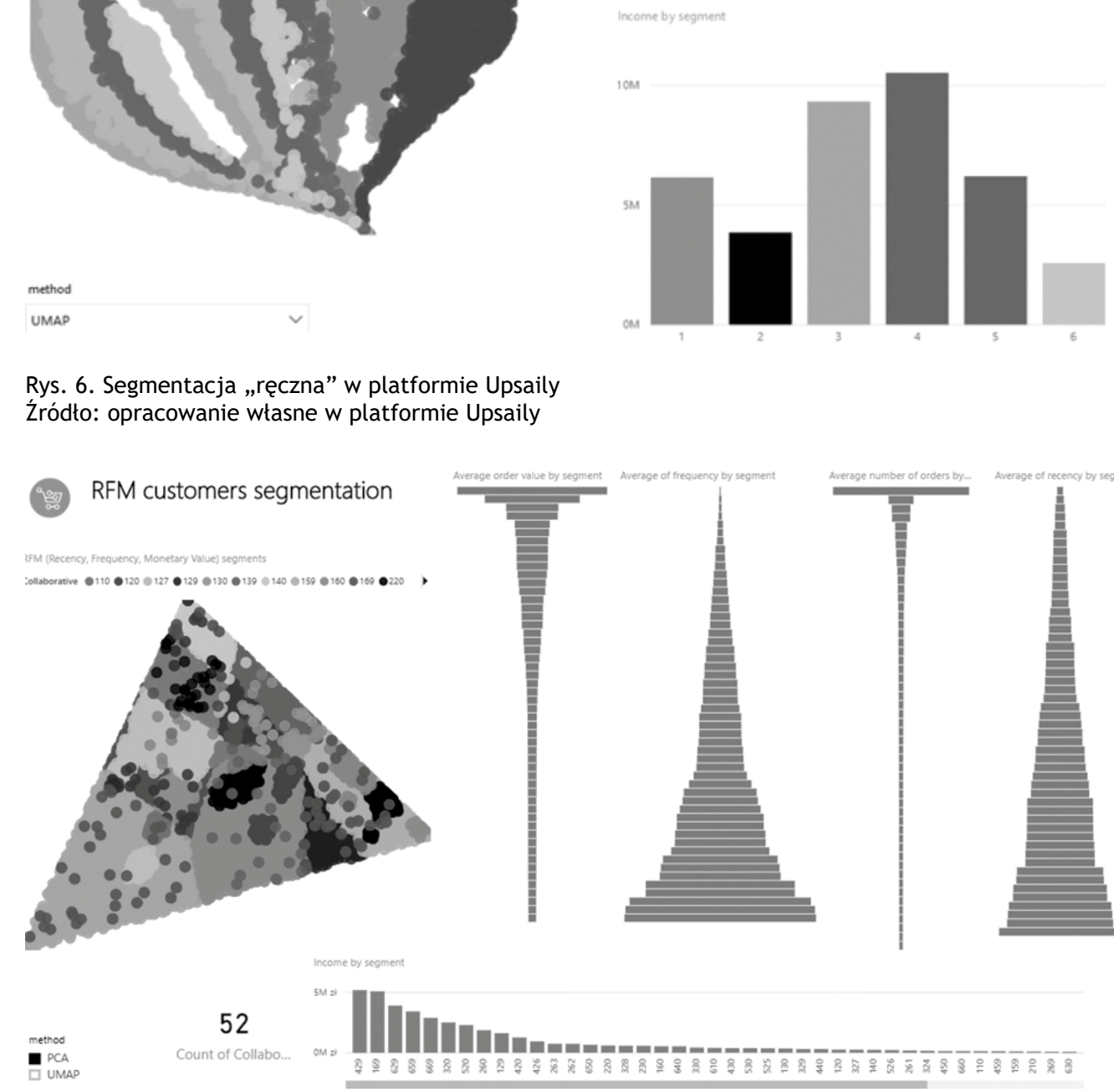

Rys. 7. Wizualizacja 52 segmentów przygotowanych z uwaględnieniem podejścia kolektywnego Źródto: opracowanie wtasne w platformie Upsaily 


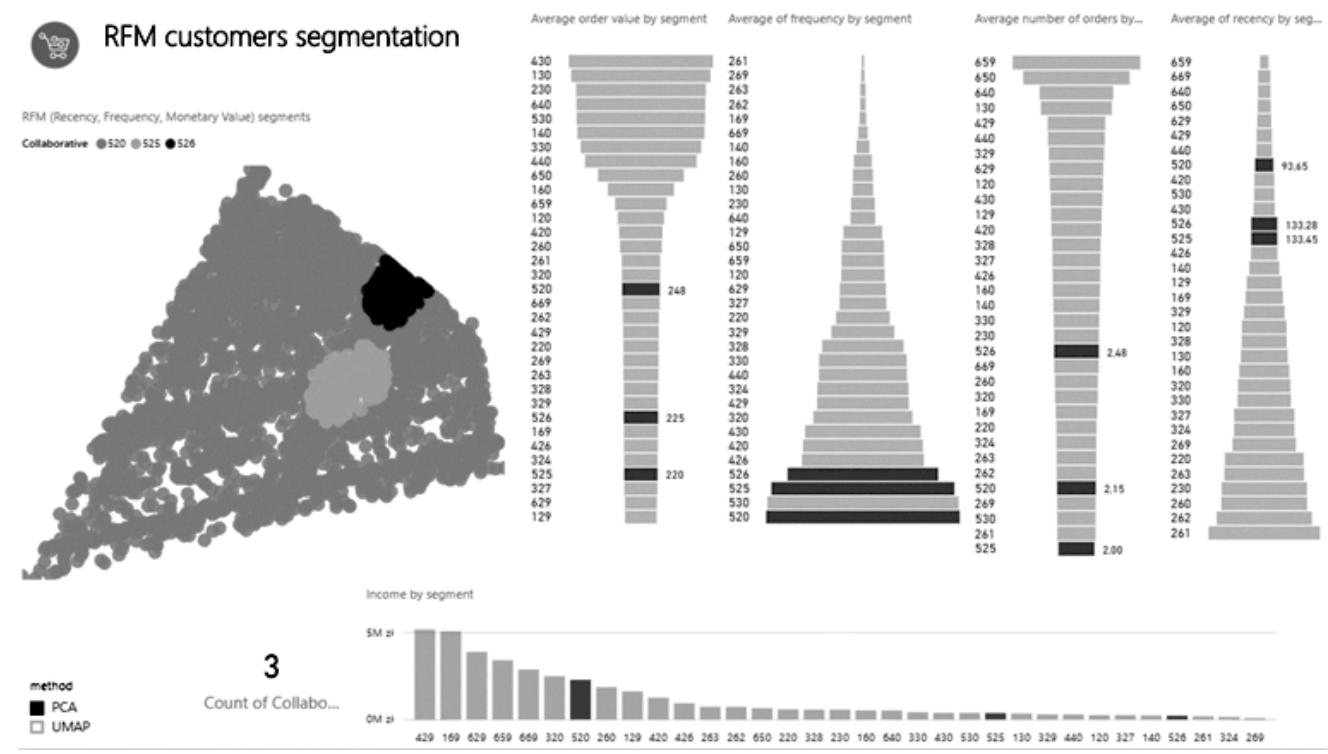

Rys. 8. Wizualizacja połączenia trzech podobnych klastrów przygotowanych z uwzględnieniem podejścia kolektywnego

Źródło: opracowanie wtasne w platformie Upsaily

efekty działania trzech wybranych algorytmów segmentacji. Z uwagi na bardzo podobne rezultaty działania $\mathrm{k}$-means oraz bisecting k-means zrezygnowano $\mathrm{z}$ użycia $\mathrm{w}$ eksperymencie rezultatów działania algorytmu k-means. Każdego klienta przypisano do trójki wygenerowanej z numerów segmentów otrzymanych przy użyciu algorytmów: bisecting k-means, GMM, DBSCAN. $\mathrm{Na}$ przykład segment 326 oznacza, że klient znalazł się $\mathrm{w}$ segmentach o numerach: 3 - bisecting k-means; 2 - GMM; 6 - DBSCAN. W rezultacie powstały $52 \mathrm{seg}$ menty (na 216 możliwych kombinacji), co zaprezentowane zostało na rysunku 7. Tak duża liczba segmentów nie pozwala oczywiście na dogłębną analizę każdego z nich oraz „ręczne" przygotowywanie polityk marketingowych. Segmenty te mogą jednak z powodzeniem zostać wykorzystane w mechanizmie rekomendacyjnym.

$\mathrm{W}$ przypadku dużej liczby segmentów można się podjąć próby złączenia klastrów. Przykładowo, jeżeli analityk zdecyduje o maksymalnej liczbie klastrów lub o minimalnej liczności klastra, wówczas segmenty o liczności poniżej progu włączone zostaną do większego segmentu spełniającego kryterium liczności. Złączeń klastrów można też dokonać, kierując się najniższą odległością pomiędzy nimi. Odległość klastrów nie wyznacza się miarą euklidesową, ponieważ dla każdej ze wspomnianych metod zbliżone numery klastrów nie determinują ich podobieństwa. Przez odległość w tym przypadku należy rozumieć liczbę algorytmów wskazujących inny numer klastra, np. pomiędzy klastrami 525 i 520 odległość wynosi 1 - co oznacza, że klastry różnią się wynikiem 1 metody; pomiędzy klastrami 320 i 525 odległość wynosi 2. Oczywiście identyfikując klastry, które powinniśmy poddać złączeniu, natrafimy na konflikty - może być kilka par klastrów o tej samej odległości od siebie. $\mathrm{W}$ tym eksperymencie rozwiązano ten konflikt, wybierając klaster o największej liczności, do którego dołączymy klaster niespełniający kryterium liczności. Rysunek 8 ilustruje przykładowy sposób połączenia klastrów 525 i 526 z klastrem 520 (jako najbardziej licznym).

Algorytmy k-means, bisecting k-means czy GMM wymagają podania liczby klastrów, które chcemy otrzymać. Jedynie algorytm DBSCAN samodzielnie dobiera liczbę klastrów na podstawie innych parametrów. Jednakże w jego przypadku duża część obserwacji nie znalazła się w żadnym klastrze wynikowym, tym samym ogranicza to jego zastosowanie w zdefiniowaniu polityk marketingowych obejmujących wszystkich klientów. Natomiast świetnie nadaje się on do identyfikacji mniejszych grup obserwacji, które są do siebie bardzo podobne.

Reasumując, segmentacja przy użyciu kilku wybranych algorytmów jest bardziej interesująca $\mathrm{z}$ perspektywy analityka marketingu niż segmentacja przy użyciu wyłącznie jednego algorytmu. Przede wszystkim otrzymane klastry w wyniku kolektywnej klasteryzacji posiadają lepszą i bardziej użyteczną marketingowo semantykę. Ponadto analityk może samodzielnie podjąć decyzję, czy przy użyciu opisanego podejścia skupić się na określeniu optymalnej liczby dużych klastrów, czy w celu identyfikacji ukrytych wzorców zachowań klientów przeanalizować mniejsze skupienia.

\section{Podsumowanie}

S ystem Upsaily wykorzystuje klastering jako jedną z metod analizy i eksploracji działań klientów na potrzeby generowania rekomendacji zakupowych. Analiza RFM pozwoliła odpowiedzieć na pytanie, kiedy oraz o jakiej wartości produkty zarekomendować klientowi. Dodatkowo, w celu doprecyzowania rekomendacji kierowanych do klienta $\mathrm{w}$ systemie Upsaily można skorzystać z algorytmów klasyfikacji. Między innymi takie metody eksploracji jak reguły asocjacyjne czy reguły 
wyszukiwania wzorców sekwencyjnych uzupełniająco odpowiedziały na pytanie, jaki produkt / kategorię produktową zaoferować klientowi.

Segmentacja przy użyciu jednego algorytmu z punktu widzenia analityka marketingu zawsze ma wady, m.in. takie jak niewielkie zróżnicowanie segmentów na poszczególnych wymiarach lub segmenty o bardzo małej liczności. W celu pozbycia się wskazanych wad oraz uwypuklenia zalet każdego algorytmu zaproponowano podejście kolektywnej klasteryzacji polegające na zbudowaniu klastra poprzez unifikację segmentacji wielu algorytmów. Taka segmentacja dała bardziej spójne segmenty o łatwej interpretacji biznesowej. Małe segmenty były przydatne przy budowaniu automatycznych rekomendacji opartych na przynależności klienta do segmentu, gdzie liczba segmentów nie ma większego znaczenia. Mało liczne segmenty były również przydatne $\mathrm{w}$ kontekście identyfikacji klientów nietypowych jako wartości odstających.

$\mathrm{W}$ kolejnych pracach autorzy zajmą się tematyką klasteryzacji kolaboracyjnej, automatyczną identyfikacją optymalnej liczby segmentów, a także klasteryzacją klientów w oparciu o kolejne wymiary biorące pod uwagę przedmioty ich transakcji.

\section{prof. dr hab. Jerzy J. Korczak \\ Międzynarodowa Wyższa Szkoła \\ Logistyki i Transportu we Wrocławiu \\ Wydział Logistyki i Transportu \\ ORCID: 0000-0001-6441-6126 \\ e-mail: jerzy.korczak@ue.wroc.pl}

\section{dr inż. Maciej Pondel \\ Uniwersytet Ekonomiczny we Wrocławiu \\ Wydział Zarządzania, Informatyki i Finansów \\ ORCID: 0000-0002-1978-6571 \\ e-mail: maciej.pondel@ue.wroc.pl}

\section{Przypisy}

1) System Upsaily został zrealizowany w zespole Unity S.A, Wrocław, na podstawie prac badawczych przeprowadzonych w ramach projektu Real-Time Omnichannel Marketing (RTOM) w ramach poddziałania RPO WD 2014-2020.

2) Wskaźnik Daviesa-Boudina jest obliczany według formuły: $D B=0.5 n \sum \max \left(\left(s_{i}+s_{j}\right) / d\left(c_{i}, c_{j}\right)\right.$

gdzie $n$ oznacza liczbę klastrów, $c_{i}$ i $c_{j}$ centroidy klastrów, $\mathrm{s}_{i}$ i $\mathrm{s}_{j}$ średnie odległości $d$ między elementami danego klastra i centroidem. Algorytm generujący najmniejszą wartość wskaźnika $D B$ jest uważany za najlepszy według kryterium oceny wewnętrznej.

3) Wskaźnik Dunna jest obliczany według formuły:

$D=\min \left(d(i, j) / \max d^{\prime}(k)\right.$.

gdzie $d(i, j)$ oznacza odległość między klastrami $i$ i j , zaś $d^{\prime}(k)$ miarę odległości wewnątrz klastra $k$. Wskaźnik Dunna koncentruje się na gęstości klastrów i odległości między klastrami. Algorytmy preferowane według wskaźnika Dunna to te, które osiągają wysokie wartości wskaźnika.
4) Wskaźnik jednorodności klastrów obliczany według wzoru: $W J K=1 / N \sum \max |m \cup d|$ gdzie $M$ oznacza liczbę klastrów utworzonych przez algorytm, $D$ liczbę klas eksperta.

5) Wskaźnik Jaccarda mierzy podobieństwo miedzy dwoma zbiorami obserwacji według następującego wzoru:

$W J=T P /(T P+F P+F N)$. W przypadku dwóch identycznych zbiorów $W J=1$.

6) Wskaźnik Randa jest obliczany według wzoru: $W R=(T P+T N) /(T P+F P+F N+F N)$.

Wskaźnik Randa, jak i poprzednie, oparty jest na porównaniu $\mathrm{z}$ benchmarkiem podanym przez eksperta. Informuje on o podobieństwie oceny prawidłowych decyzji między wynikami algorytmu klasteryzacji a benchmarkiem.

7) W systemie użyto algorytmu HDBSCAN, który stanowi rozbudowę algorytmu DBSCAN. Użyto w tym celu biblioteki dostępnej w platformie GitHub https://hdbscan.readthedocs. io/en/latest/index.html.

8) Celem metody PCA, w skrócie, jest znalezienie liniowej podprzestrzeni w naszym przypadku 2-wymiarowej, w której wariancja po dokonaniu projekcji pozostaje największa. Metoda PCA nie polega jednak na odrzuceniu wymiarów o najniższej wariancji, tylko na zbudowaniu nowego układu współrzędnych, w którym pozostałe wartości pozostają najbardziej zróżnicowane.

\section{Bibliografia}

[1] Acilar A.M., Arslan A. (2019), A Collaborative Filtering Method Based on Artificial Immune Network, „Expert System Applications", Vol. 36, No. 4, pp. 8324-8332.

[2] Adamovicius G., Tuzhilin A. (2005), Toward the Next Generation of Recommender Systems: A Survey of the State-of-the-art and Possible Extensions, „IEEE Trans. on Knowledge and Data Engineering”, Vol. 17, No. 6, pp. 734-749.

[3] Aggarval C.C. (2013), Data Clustering: Algorithms and Applications, Chapman \& Hall, CRC Press, Boca Raton.

[4] Ayad H., Kamel M.S. (2008), Cumulative Voting Consensus Method for Partitions with Variable Number of Clusters, , „IEEE Transactions on Pattern Analysis and Machine Intelligence”, Vol. 30, No. 1, pp. 160-173.

[5] Balabanovic M., Shoham Y. (1997), Content-based, Collaborative Recommendation, "Communications of the ACM”, Vol. 40, No. 3, pp. 66-72.

[6] Beel J. (2015), Towards Efective Research-paper Recommender Systems and User Modeling Based on Mind Maps, PhD Thesis, Otto-von-Guericke Universität Magdeburg.

[7] Burke, R. (2002), Hybrid Recommender Systems: Survey and Experiments, „User Modeling User-Adaption Interaction”, Vol. 12, No. 4, pp. 331-370.

[8] Carmagnola F., Cena F., Gena C. (2011), User Model Interoperability: A survey, „User Modeling User-Adaption Interaction", Vol. 21, No. 3, pp. 285-331.

[9] Cornuejols A., Wemmer C., Gançarski P., Bennani Y. (2017), Collaborative Clustering: Why, When, What and How, „Information Fusion”, Vol. 39, pp. 81-95. 
[10] Chorianopoulos A. (2016), Effective CRM Using Predictive Analytics, John Wiley \& Sons, Chichester.

[11] Gan G., Ma C., Wu J. (2007), Data Clustering: Theory, Algorithms, and Applications, SIAM Series.

[12] Grira N., Crucianu M., Boujemaa N. (2008), Active Semi-supervised Fuzzy Clustering, „Pattern Recognition”, Vol. 41, No. 5, pp. 1851-1861.

[13] Faceli K., Ferreira de Carvalho A.C., Pereira de Souto M.G. (2007), Multiobjective Clustering Ensemble with Prior Knowledge, Vol. 4643, pp. 34-45, Springer.

[14] Gancarski P., Cornueejols A., Wemmert C., Bennani Y. (2017), Clustering Collaboratif: Principes et Mise en Oeuvre, Proc. BDA'17, Nancy.

[15] Ghodsi A. (2006), Dimensionality Reduction a Short Tutorial, Department of Statistics and Actuarial Science, Univ. of Waterloo, Ontario, Canada, 37, p. 38.

[16] Goldberg D., Nichols D., Oki B.M., Terry D. (1992), Using Collaborative Filtering to Weave an Information Tapestry, "Communications of the ACM", Vol. 35, No. 12, pp. 61-70.

[17] Gordon S., Linoff M., Berry J.A. (2011), Data Mining Techniques: For Marketing, Sales, and Customer Relationship, John Wiley \& Sons, Chichester.

[18] Jannach D., Zanker M., Felfernig A., Friedrich G. (2010), Recommender Systems - An Introduction, Cambridge University Press.

[19] Jannach D., Zanker M., Ge M., Gröning M. (2012), Recommender Systems in Computer Science and Information Systems-a Landscape of Research, Proc. of the 13th International Conference, EC-Web, pp. 76-87.

[20] Jordan M.I., Mitchell T.M. (2015), Machine Learning: Trends, Perspectives, and Prospects, „Science”, Vol. 349, No. 6245, pp. 255-260.

[21] Kashef R., Kamel M.S. (2010), Cooperative Clustering, „Pattern Recognition”, Vol. 43, No. 6, pp. 2315-2329.

[22] Kobiela E. (2011), Inteligentne systemy rekomendacyj$n e$, Network Magazyn, http://www.networkmagazyn. $\mathrm{pl} /$ inteligentne-systemy-rekomendacji, data dostępu: $01.10 .2018 \mathrm{r}$.

[23] Konstan J.A., Riedl J. (2012), Recommender Systems: From Algorithms to User Experience, „User Modeling User-Adaption Interaction", Vol. 22, pp. 101-123.

[24] Konstan J.A., Adomavicius G. (2013), Toward Identification and Adoption of Best Practices in Algorithmic Recommender Systems Research, Proceedings of the International Workshop on Reproducibility and Replication in Recommender Systems Evaluation, pp. 23-28.

[25] Law M.H., Topchy A., Jain A.K. (2004), Multiobjective Data Clustering, „IEEE Conference on Computer Vision and Pattern Recognition", Vol. 2, pp. 424-430.

[26] Linoff G.S. (2015), Data Analysis Using SQL and Excel, John Wiley \& Sons.

[27] McInnes L., Healy J. (2018), UMAP: Uniform Manifold Approximation and Projection for Dimension Reduction, arXiv preprint arXiv:1802.03426.

[28] Nazemoff V. (2014), Customer Intelligence, [in:] The Four Intelligences of the Business Mind, Apress, Berkeley,

[29] Nguyen N., Caruana R. (2007), Consensus Clusterings, International Conference on Data Mining, IEEE Computer Society, pp. 607-612.
[30] Palopoli L., Rosaci D., Sarné G.M. (2013), A Multi-tiered Recommender System Architecture for Supporting E-Commerce, [in:] G. Fortino, C. Badica, M. Malgeri, R. Unland (eds.) Intelligent Distributed Computing VI, Springer, pp. 71-81.

[31] Pedrycz W. (2007), Collaborative and Knowledge-based Fuzzy Clustering, „International Journal of Innovative, Computing, Information and Control", Vol. 1, No. 3, pp. 1-12.

[32] Quinlan J. (1996), Improved Use of Continuous Attributes in $\{C 4.5\}$, „Journal of Artificial Intelligence Research", Vol. 4, pp. 77-90.

[33] Resnick P., Varian H.R. (1997), Recommender Systems, "Communications of the ACM", Vol. 40, No. 3, pp. 56-58.

[34] Ricci F., Rokach L., Shapira B., Kantor P.B. (eds), (2011), Recommender Systems Handbook, Springer, pp. 1-35.

[35] Sublemontier J.H. (2013), Unsupervised Collaborative Boosting of Clustering: A Unifying Framework for Multi-view Clustering, Multiple Consensus Clusterings and Alternative Clustering, International Joint Conference on Neural Networks.

[36] Said A., Tikk D., Shi Y., Larson M., Stumpf K., Cremonesi P. (2012), Recommender Systems Evaluation: a $3 d$ Benchmark, ACM RecSys 2012 Workshop on Recommendation Utility Evaluation: Beyond RMSE, pp. 21-23.

[37] Wagstaff K., Cardie C., Rogers S., Schroedl S. (2001), Constrained K-means Clustering with Background Knowledge, International Conference on Machine Learning, pp. 557-584.

[38] Wemmert C., Gancarski P., Korczak J. (2000), A Collaborative Approach to Combine Multiple Learning Methods, „International Journal on Artificial Intelligence Tools (World Scientific)", Vol. 9, No. 1, pp. 59-78.

\section{Collective Clustering of Marketing Data - Upsaily Recommendation System}

\section{Summary}

The article presents new data mining methods in the recommendation system, addressed to online store managers. The article discusses the use of cluster analysis algorithms utilised to discover market segments. In general, the results of individual algorithms differ from one another, and can create problems with interpretation and management. Using the results of several classical algorithms, supported by the RFM segmentation, a method of collective clustering has been proposed. The concept and advantages of unifying the results of clustering the algorithms have been verified on a large, real marketing database.

\section{Keywords}

recommendation systems, marketing data exploration, e-Commerce, clustering, k-means, bisecting k-means, Gaussian Mixed Model, DBSCAN, collective clustering 